\title{
ArcheoSciences
}

Revue d'archéométrie

33 (suppl.) | 2009

Mémoire du sol, espace des hommes

\section{Magnetic survey on the tell of Qinnasrin (Syria)}

Yves Bière, Marie-Odile Rousset and Christophe Benech

\section{(2) OpenEdition}

\section{Journals}

Electronic version

URL: https://journals.openedition.org/archeosciences/1591

DOI: 10.4000/archeosciences.1591

ISBN: 978-2-7535-1599-4

ISSN: 2104-3728

Publisher

Presses universitaires de Rennes

Printed version

Date of publication: 30 October 2009

Number of pages: $205-207$

ISBN: 978-2-7535-0943-6

ISSN: 1960-1360

Electronic reference

Yves Bière, Marie-Odile Rousset and Christophe Benech, "Magnetic survey on the tell of Qinnasrin

(Syria)", ArcheoSciences [Online], 33 (suppl.) | 2009, Online since 30 October 2011, connection on 01 February 2022. URL: http://journals.openedition.org/archeosciences/1591 ; DOl: https://doi.org/ 10.4000/archeosciences.1591 


\title{
Magnetic survey on the tell of Qinnasrin (Syria)
}

\author{
Yves Bière*, Marie-Odile Rousset ${ }^{* *}$ and Christophe BeneCH ${ }^{* * *}$
}

Key words: Magnetic survey, City planning, Byzantine period, Islamic period, Syria.

The program of research on the site of Qinnasrin (Syria) has been managed since 2003 in collaboration with the direction of Syrian Antiquities and Museums and the Archeological Museum of Aleppo. Qinnasrin is generally recognized as the classical city of Calchis, near the modern village of al-'Iss, $25 \mathrm{~km}$ to south-west from Aleppo (Mouterde an Poidebard, 1945). The project scope is the study of one of the first of Islamic cities from Northern Syria which has been the capital of the regional province From VII ${ }^{\text {th }}$ until $\mathrm{X}^{\text {th }}$ Century BC. The study takes into account the most ancient elements which conditioned the formation of the city and follows its evolution until its abandonment.

The site is located on the piedmont (foothills) of the south-east extremity of the calcareous massif from Northern Syria (Fig. 1 and 2). The top of the mountain is a remarkable point of observation between ploughed areas and steppish land: a fortification was built here between the $\mathrm{VI}^{\text {th }}$ and $\mathrm{IX}^{\mathrm{th}}$ Century $\mathrm{AD}$ was controlled the entire region. The first campaign in 2008 allowed us to determine the extension of the domestic dwellings for the different periods and to identify the main elements, between the fortification on the mountain and the city itself (fortifications, tell/acropolis/citadel, residential quarters, necropolis, quarries, artisanal areas...).

Following the tradition, the city of Calchis should have been founded by Seleukos $1^{\text {st }}$ at the beginning of the III ${ }^{\text {rd }}$ Century BC. An occupation from the Hellenistic period (II ${ }^{\text {nd }}$ c. B.C.) has been identified with traces of a hippo- damian plan (Monceaux and Brossé, 1925, Fourdrin and Feissel, 1994).

During the byzantine period, the city reached its maximal extent, with a fortress on the tell, domestic dwellings at the bottom of the tell surrounded by fortifications and suburbs outside dedicated to the artisanal and commercial activities. The fortifications of the byzantine city are still visible and an inscription on the door attests to a restoration in $550 \mathrm{AD}$.

During the omeyyad period (middle of VII ${ }^{\text {th }}$ - middle VIII ${ }^{\text {th }}$ Century), the occupation of the city reduced to the tell and to its immediate neighborhood inside the ancient byzantine city wall. The fortification of the mountain could have been made during this period.

With the Abbasid period (IX ${ }^{\text {th }}-\mathrm{X}^{\text {th }}$ Century), we observe a new extension of the occupation in the northern sector and on the mountain which certainly had been a refuge during the military campaigns between Byzantines and Muslims. We also know that Qinnasrin was, in the first half of the $\mathrm{X}^{\text {th }}$ Century, a rich agricultural region and a prosperous city.

In the $\mathrm{XI}^{\text {th }}$ Century, Qinnasrin was reduced to a village installed on the tell where some remains of this last occupation are still visible.

* Université de Bourgogne.

** Maison de l'Orient et de la Méditerranée, UMR 5189 Hisoma.

*** Maison de l'Orient et de la Méditerranée, UMR 5133 Archéorient. 


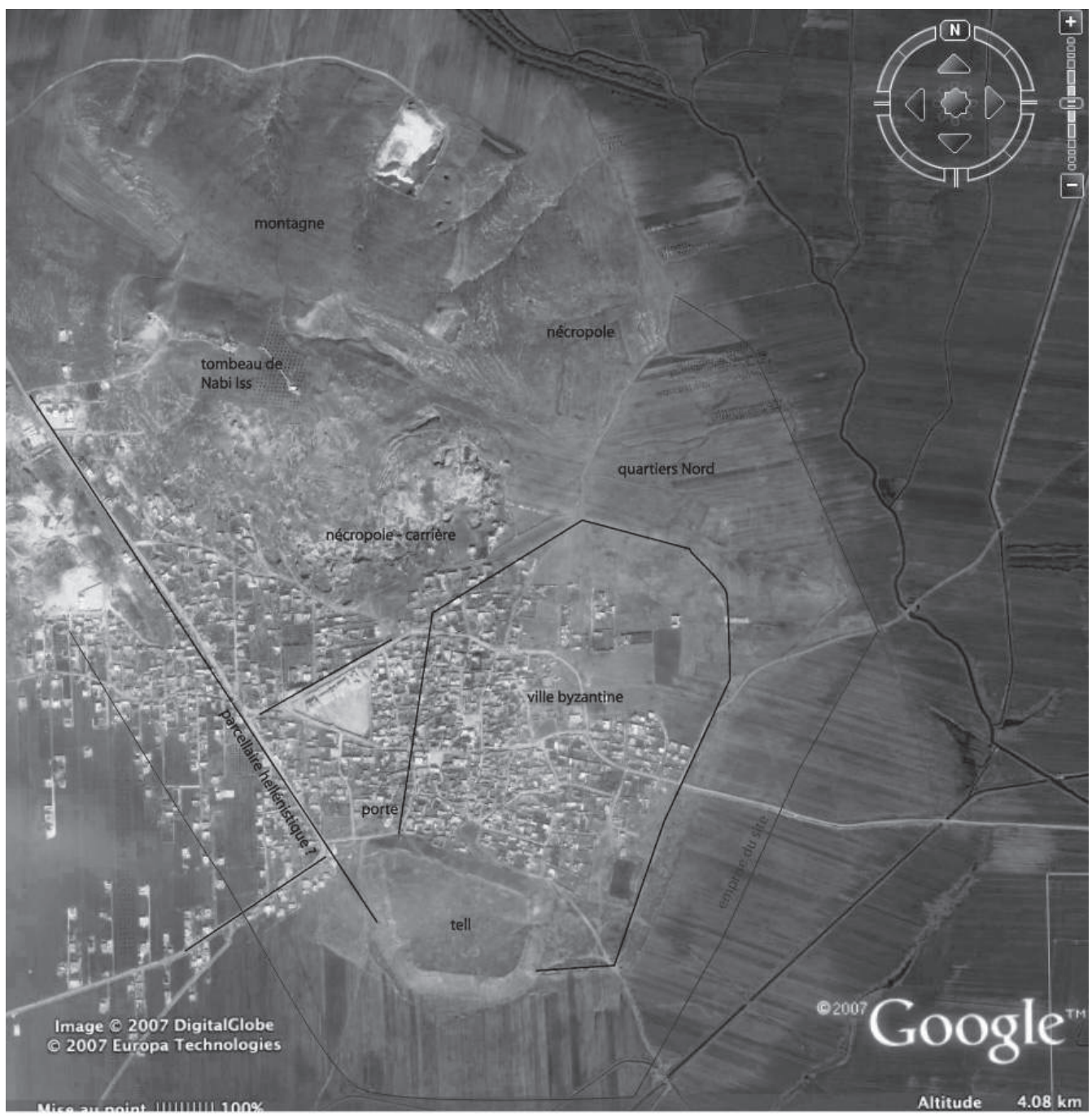

Figure 1: Aerial view (google) of the site.

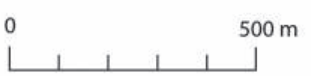

\section{Magnetic Survey}

A magnetic survey, with a Cesium gradiometer G858 (Geometrics), has been carried out on the top of the tell which represents a surface of around 8 ha (Fig. 3). In spite of multiple occupations of the tell, we obtained a magnetic map with rather clear results: many streets and buildings and also a part of the fortifications are visible and give a good idea of the spatial organization of the tell.

We can first observe that this organization is the result of a long evolution: the organization we can observe here doesn't correspond to a specific plan but seems have rather freely evolved following the destructions and reconstructions of the buildings.

We have nevertheless some elements which reveal a more planned organization, particularly if we consider buildings orientations and streets. The organization on the tell is dominated by two major orientations: the first one $\left(14,3^{\circ}\right.$ to the east) concerns all the eastern part of the tell and also a big section of the north-western part along the fortification. This orientation looks to be imposed by the shape of the northern limit of the tell. The second orientation $\left(14,5^{\circ}\right.$ to the west) is more limited to the south-western quarter of the tell and all along the western fortification, following the western limit of the tell.

As we could expect the organization is therefore influenced by the shape of the tell and both orientations allow the optimization of the use of the space inside the fortifications. Consequently, they don't necessarily correspond to different periods but can be contemporaneous and have been planned together. A more detailed analysis of the connection between the buildings belonging to each orientation will certainly give us more information. 


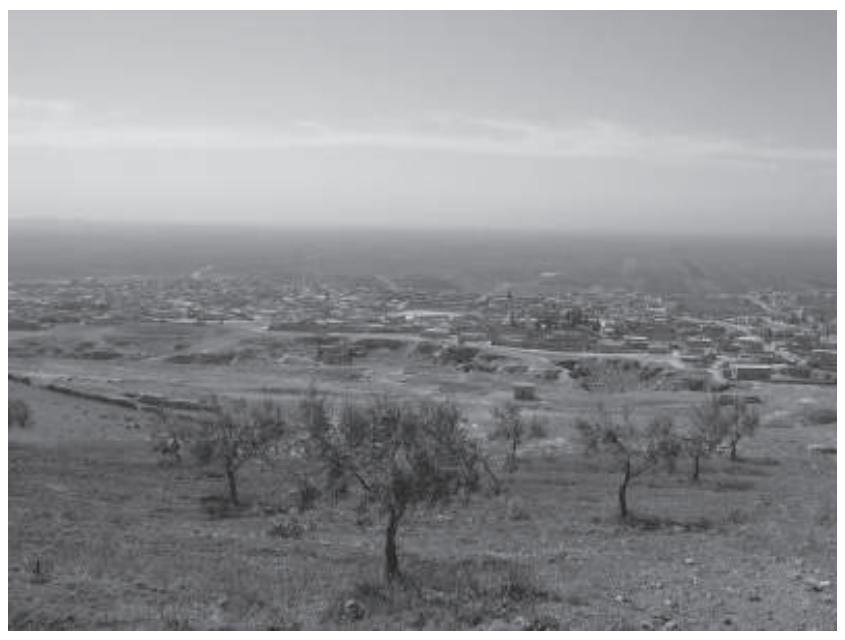

Figure 2 : View from the tell of the Byzantine town.

We easily recognize on the magnetic map street segments belonging to both orientations but this network doesn't look continuous and seems to have been deeply modified, even if the main streets were probably still connected with the doors of the fortification. Nevertheless, the circulation on the tell is not obvious to understand and many streets look to have evolved to dead ends. Another significant element of the organization is non-built areas which there are several. They could correspond to some parts which have been destroyed and not reconstructed but all these places seem to have an important role in the distribution of the circulation. The understanding of the connection of all these different elements will probably give a better idea of the logic of occupation on the tell and its evolution.

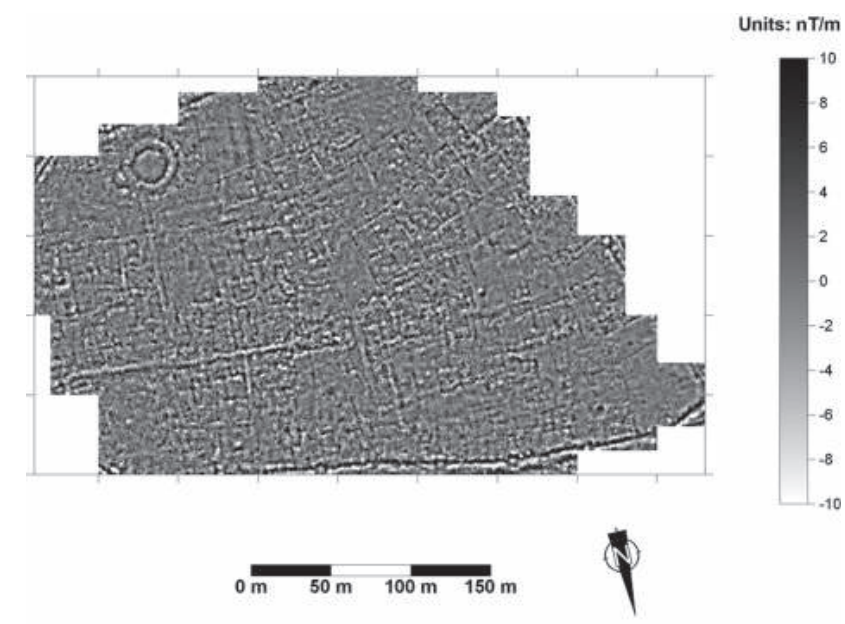

Figure 3 : Magnetic survey on the tell.

\section{References}

Fourdrin, J.-P. and FeIssel, D., 1994. Une porte urbaine construite à Chalcis de Syrie par Isidore de Milet Le Jeune (550-551), Travaux et Mémoires, 12 : 299-307.

Monceaux, P., Brossé, L., 1925. Chalcis ad Belum. Notes sur l'histoire et les ruines de la ville, Syria, 6: 339-350.

Mouterde, R., Poidebard, A., 1945. Le limes de Chalcis : organisation de la steppe en haute Syrie romaine, Bibliothèque Archéologique et Historique; 38. 